\title{
Comparative cytotoxic and anti-tuberculosis activity of Aplysina caissara marine sponge crude extracts
}

\author{
Luciana G. Azevedo $^{\mathrm{a}, \mathrm{b}}$, Ana L. Muccillo-Baisch ${ }^{\mathrm{a}, \mathrm{b}}$, Daza de M.V.B. Filgueira ${ }^{\mathrm{a}, \mathrm{b}}$, \\ Robert T. Boyle ${ }^{\mathrm{b}}$, Daniela F. Ramos ${ }^{\mathrm{c}}$, Andrea D. Soares ${ }^{\mathrm{d}}$, Clea Lerner ${ }^{\mathrm{e}}$, \\ Pedro A. Silva ${ }^{\text {c }}$, Gilma S. Trindade ${ }^{\mathrm{a}, \mathrm{b}, *}$ \\ a Departamento de Ciências Fisiológicas, Fundação Universidade Federal do Rio Grande (FURG), Rio Grande, (96201-900), Brazil \\ b Programa de Pós-graduação em Ciências Fisiológicas, Fisiologia Animal Comparada (FURG), Rio Grande, (96201-900), Brazil \\ ${ }^{\mathrm{c}}$ Departamento de Patologia (FURG), Rio Grande, (96201-900), Brazil \\ ' Departamento de Oceanografia (FURG), Rio Grande, (96201-900), Brazil \\ ${ }^{\text {e }}$ Fundação Zoobotânica do Rio Grande do Sul, Porto Alegre, Brazil
}

Received 28 March 2007; received in revised form 23 July 2007; accepted 24 July 2007

Available online 1 August 2007

\begin{abstract}
Three crude extracts of Aplysina caissara, a marine sponge endemic to Brazil, were tested against a hepatoma cell line and Mycobacterium tuberculosis. The results demonstrate that all extracts are toxic and capable of inhibiting cellular growth. Additionally, the extracts produced morphological aberrations and inhibited cell attachment to culture substrates. These effects were dose/time dependent. Our results also suggest that reactive oxygen species (ROS) production is not involved in the cytotoxic processes levied by the extracts employed in this study and that active metabolites are likely to be present in the polar fractions of the crude extracts. Finally, our results indicate that all three extracts exhibit a moderate anti-tuberculosis capacity, and that the removal of an extract's lipid fraction appears to diminish this activity.
\end{abstract}

(C) 2007 Elsevier Inc. All rights reserved.

Keywords: Aplysina caissara marine sponge; Anti-tuberculosis assay; Cytotoxic assay

\section{Introduction}

Covering around $70 \%$ of the planet surface, the world's oceans possess a huge potential for the discovery of novel pharmaceuticals (Monks et al., 2002). According to the relevant marine literature, Porifera are the most widely studied phylum in this regard (Munro et al., 1999; Faulkner, 2002); thus it may come as no surprise that this group possesses the majority of the known marine invertebrate metabolites (Urban et al., 2000; Kijjoa and Sawangwong, 2004; Hunt and Vincent, 2006). Marine natural products are emerging as an alternative source for new drugs and could play an important role in the treatment

\footnotetext{
* Corresponding author. Departamento de Ciências Fisiológicas, Fundação Universidade Federal do Rio Grande (FURG), Rio Grande, (96201-900), Brazil. Tel./fax: +55 $5332336855 /+555332336850$.

E-mail address: gilma.trindade@gmail.com (G.S. Trindade).
}

of human diseases such as cancer and tuberculosis (TB). In this study, the special attention we pay to these two diseases is based upon the fact that cancer remains one of the leading causes of death in developing countries (Kraljevic et al., 2006) and $\mathrm{TB}$ is an infectious disease of large impact on public health throughout the world, causing around two million deaths annually (WHO, 2000). Therefore, the investigation of alternative treatments for these diseases is relevant.

A comparative study regarding the sources of bioactive compounds with pharmaceutical potential was published based upon statistical data from the US National Cancer Institute screening program, which indicated that marine invertebrates possess a much higher incidence of compounds with significant cytotoxic activity (Munro et al., 1999), with an emphasis leaning toward certain phyla, such as Porifera, Bryozoa and Chordata (Munro et al., 1999; Urban et al., 2000). Mayer and Gustafson (2006) published a review article 
on anti-tumoral and cytotoxic marine compounds. In this review, they describe many marine sponges as sources of bioactive compounds.

Additionally, it is important to evaluate marine sponges as a possible treatment for TB since certain sponge metabolites have shown promising anti-TB activity (Nicholas et al., 2003; Mayer and Hamann, 2004, 2005; Souza, 2006). Chemotherapy is a powerful weapon to control TB (Silva et al., 2001), but the acquired resistance to anti-TB drugs has contributed to the reemergence of this disease (Rattan et al., 1998; Nachega and Chaisson, 2003; WHO, 2006).

The order Verongida is known to possess secondary metabolites that are bromotyrosine derivatives of widely varying complexities (Hamann and Scheuer, 1993). In this order, many species of the genus Aplysina possess compounds with antitumoral and anti-microbial activity. These anti-tumoral effects were observed in the human colon tumor (HTC 116) cell line, in the tumoral cell lines MCF-7 and CCRF-CEM (Rodriguez and Piña, 1993), in murine lymphoma L-1210 and human epidermoid carcinoma KB cells (Kondo et al., 1994), in Ehrlich ascites tumor (EAT) cells and HeLa tumor cells (Koulman et al., 1996). Antimicrobial activity has been shown against Staphylococcus aureus, Pseudomonas aeruginosa and Escherichia coli (Rodriguez and Piña, 1993), against Mycobacterium tuberculosis (Encarnación et al., 2000) and against gram-positive and gram-negative marine bacteria including Alteromonas, Moraxella, and Vibrio spp. (Ebel et al., 1997).

The marine sponge Aplysina caissara (Pinheiro and Hadju, 2001), an endemic Brazilian species of the order Verongida, also possesses known bromotyrosine compounds (Saeki et al., 2002; Lira et al., 2006) such as Fistularin-3 and 11-hydroxyaerothionin which display moderate antibiotic activity against $E$. coli, $P$. aeruginosa and $S$. aureus (Lira et al., 2006).

In light of all of these reported activities of pharmacological interest, the aim of this work was to compare the cytotoxic and
anti-TB activity of the three crude extracts from marine sponge A. caissara.

\section{Material and methods}

\subsection{Sponge collection}

Samples of $A$. caissara were collected by SCUBA-divers at depths of $15 \mathrm{~m}$ (first collection) and $7 \mathrm{~m}$ (second collection), on Arvoredo Island, in the state of Santa Catarina (southeastern Brazil). The first collection was made in July of 2005 and these samples were directly immersed in ethanol. Samples from the second collection, in April of 2006, were immediately frozen under dry ice $\left(-78.5^{\circ} \mathrm{C}\right)$. Both collections were sent to the Laboratório de Produtos Naturais do Departamento de Ciências Fisiológicas - FURG where the samples from the second collection were transferred from the dry ice to ethanol. All samples were maintained at $-20{ }^{\circ} \mathrm{C}$, and subsequently identified by Dr. Clea Lerner. Some specimens were deposited in the Museu de Ciências Naturais, Fundação Zoobotânica of Rio Grande do Sul, Brazil - Porifera collection (MCNPOR).

\subsection{Extract preparation}

The sponge was extracted in ethanol (which was reserved) and the remaining material was sequentially extracted four times by maceration in methanol $(0.3 \mathrm{~g} / \mathrm{mL})$, over 4 days. The methanolic solution was reserved each of these days. After the fourth day, the ethanol and methanol solutions were blended, filtered, concentrated in a rotary evaporator and dried in a SpeedVac. A portion of the solution extracted from samples collected in 2006 was partitioned against hexane $(1: 1, \mathrm{v} / \mathrm{v})(100 \%)$, the lipid portion was removed, and then the polar fraction was dried in a SpeedVac.

Thus, for this study, three extracts were tested: Ac05 collected in 2005, Ac06 collected in 2006 and Ac06H collected in 2006 and partitioned against hexane.

Table 1

Viability (\%) of HTC cells exposed to different extracts and concentration

\begin{tabular}{|c|c|c|c|c|c|}
\hline \multirow[t]{2}{*}{ Extract } & \multirow{2}{*}{$\begin{array}{l}\text { Concentration } \\
(\mu \mathrm{g} / \mathrm{mL})\end{array}$} & \multicolumn{4}{|l|}{ Time (h) } \\
\hline & & 0 & 24 & 48 & 72 \\
\hline \multirow[t]{4}{*}{ Ac05 } & 0 & $(96.71 \pm 0.42 \%)$ & $(97.27 \pm 0.64 \%)$ & $(96.86 \pm 0.64 \%)$ & $(96.82 \pm 0.39 \%)$ \\
\hline & 500 & $(94.89 \pm 0.79 \%)$ & $(92.79 \pm 1.34 \%)$ & $(94.84 \pm 0.59 \%)$ & $(91.53 \pm 0.98 \%)$ \\
\hline & 1000 & $(93.46 \pm 1.08 \%)$ & $(84.78 \pm 2.04 \%)^{*}$ & $(67.41 \pm 2.30 \%)^{*}$ & $(53.50 \pm 3.75 \%)^{*}$ \\
\hline & 2000 & $(96.69 \pm 0.74 \%)$ & $(22.48 \pm 5.17 \%)^{*}$ & $(8.30 \pm 2.26 \%)^{*}$ & $(5.65 \pm 1.02 \%)^{*}$ \\
\hline \multirow[t]{4}{*}{ Ac06 } & 0 & $(95.92 \pm 0.61 \%)$ & $(96.98 \pm 0.39 \%)$ & $(96.99 \pm 0.83 \%)$ & - \\
\hline & 25 & $(95.57 \pm 0.75 \%)$ & $(97.76 \pm 0.48 \%)$ & $(95.91 \pm 0.68 \%)$ & - \\
\hline & 100 & $(95.46 \pm 1.03 \%)$ & $(96.55 \pm 0.84 \%)$ & $(93.06 \pm 1.0 \%)$ & - \\
\hline & 400 & $(92.55 \pm 1.65 \%)$ & $(25.16 \pm 3.54 \%)^{*}$ & $(5.32 \pm 1.37 \%)^{*}$ & - \\
\hline \multirow[t]{6}{*}{$\mathrm{Ac} 06 \mathrm{H}$} & 0 & $(96.61 \pm 0.49 \%)$ & $(97.9 \pm 0.53 \%)$ & $(96.99 \pm 0.37 \%)$ & $(94.72 \pm 0.89 \%)$ \\
\hline & 25 & $(94.92 \pm 0.53 \%)$ & $(97.47 \pm 0.72 \%)$ & $(97.38 \pm 0.38 \%)$ & $(95.15 \pm 0.81 \%)$ \\
\hline & 50 & $(95.47 \pm 0.75 \%)$ & $(97.68 \pm 0.49 \%)$ & $(97.42 \pm 0.41 \%)$ & $(92.97 \pm 1.06 \%)$ \\
\hline & 100 & $(95.13 \pm 1.07 \%)$ & $(95.18 \pm 1.33 \%)$ & $(89.77 \pm 1.23 \%)$ & $(84.99 \pm 1.39 \%)$ \\
\hline & 200 & $(94.06 \pm 1.07 \%)$ & $(80.55 \pm 3.64 \%)^{*}$ & $(30.97 \pm 4.91 \%)^{*}$ & $(22.84 \pm 8.20 \%)^{*}$ \\
\hline & 400 & $(94.06 \pm 1.39 \%)$ & $(26.53 \pm 4.03 \%)^{*}$ & $(2.82 \pm 0.84 \%)^{*}$ & $(1.23 \pm 0.35 \%)^{*}$ \\
\hline
\end{tabular}

$\operatorname{Ac} 05$ extract $(0,500,1000$ and $2000 \mu \mathrm{g} / \mathrm{mL})$ at $0,24,48$ and $72 \mathrm{~h}$ of exposure. Ac 06 extract $(0,25,100$ and $400 \mu \mathrm{g} / \mathrm{mL})$ at 0,24 and 48 of exposure. Ac06H extract $(0,25,50$, $100,200$ and $400 \mu \mathrm{g} / \mathrm{mL})$ at $0,24,48$ and $72 \mathrm{~h}$ of exposure. * Significant difference with control cells $(0 \mu \mathrm{g} / \mathrm{mL})(p<0.05)$. 


\subsection{Culture conditions}

Hepatoma tissue culture cells (HTC) from Rattus norvegicus were obtained from the Cell Bank Collection of Rio de Janeiro (RJCB), Brazil. The cells were maintained in culture medium (RPMI 1640, GIBCO) supplemented with 10\% fetal bovine serum (GIBCO), sodium bicarbonate $(0.2 \mathrm{~g} / \mathrm{L})$, L-glutamine $(0.3 \mathrm{~g} / \mathrm{L})$, HEPES $(25 \mathrm{mM}), \beta$-mercaptoethanol $\left(5 \times 10^{-5} \mathrm{M}\right)$ and $1 \%$ antifungal and anti-microbial solution, in $25 \mathrm{~cm}^{2}$ cell culture flasks and kept at $37^{\circ} \mathrm{C}$.

\subsection{Cytotoxic assay}

For the experiments, the sponge extracts were dissolved in $0.1 \%$ dimethyl sulfoxide (DMSO, Sigma-Aldrich) and the HTC cells $\left(5 \times 10^{5}\right.$ cell $\left./ \mathrm{mL}\right)$ were cultured in 24 well plates with medium without $\beta$-mercaptoethanol. Cells treated with Ac05 and $\mathrm{Ac} 06 \mathrm{H}$ extracts were incubated for $0,24,48$ and $72 \mathrm{~h}$. The final concentrations for Ac05 extract were 500, 1000 and $2000 \mu \mathrm{g} / \mathrm{mL}$ and for Ac $06 \mathrm{H}$ were 25, 50, 100, 200 and $400 \mu \mathrm{g} / \mathrm{mL}$. The incubation times for the Ac06 extract were 0,24 and $48 \mathrm{~h}$. The concentrations tested were 25, 100 and $400 \mu \mathrm{g} / \mathrm{mL}$. Cells were allowed to attach for $24 \mathrm{~h}$ before being treated with extracts. After exposure, the medium was removed and the cells were washed with phosphate buffered saline $\left(\mathrm{Ca}^{2+}\right.$ and $\mathrm{Mg}^{2+}$-free; PBS) and then the cells were mechanically removed. Determinations of viable cell number and cellular viability were assessed by Trypan blue $(0.08 \%)$ exclusion. The $\mathrm{EC}_{50}$ (estimated concentration that induced a loss of $50 \%$ cell viability) was determined after each time of exposure to Ac06H extract only, considering cellular viability (\%) and the total number of viable cells. Additionally, the Ac06H extract was used to analyze any morphological alterations occurring at concentrations of $25,50,100,200$ and $400 \mu \mathrm{g} / \mathrm{mL}$ after $72 \mathrm{~h}$ exposure. The cells were examined using a Bioval XDS-1B inverted microscope (ocular WF 10X/20 and objective 40×).

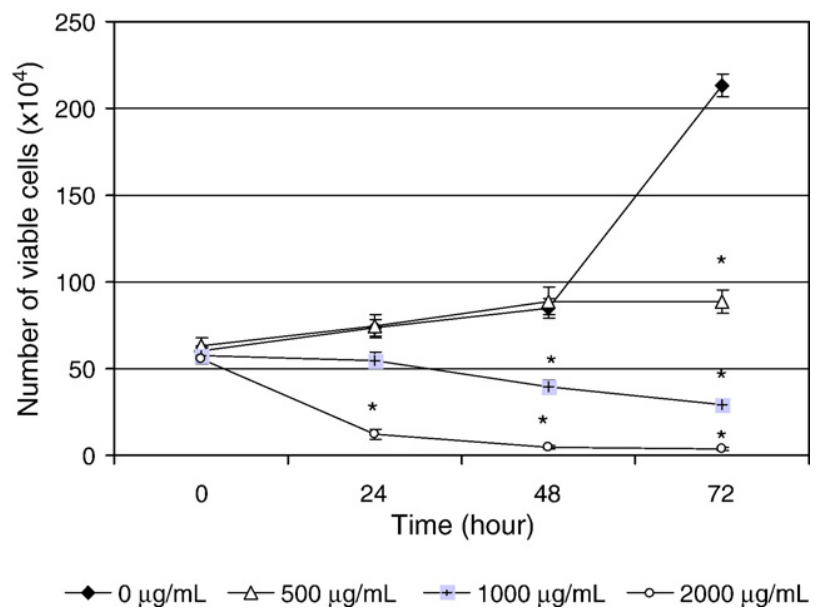

Fig. 1. Total number of viable HTC cells exposed to different concentration of Ac05 extract $(0,500,1000$ and $2000 \mu \mathrm{g} / \mathrm{mL})$ at $0,24,48$ and $72 \mathrm{~h}$ of exposure. Data expressed as means \pm standard error. * Significant difference with control cells $(0 \mu \mathrm{g} / \mathrm{mL})(p<0.05)$.

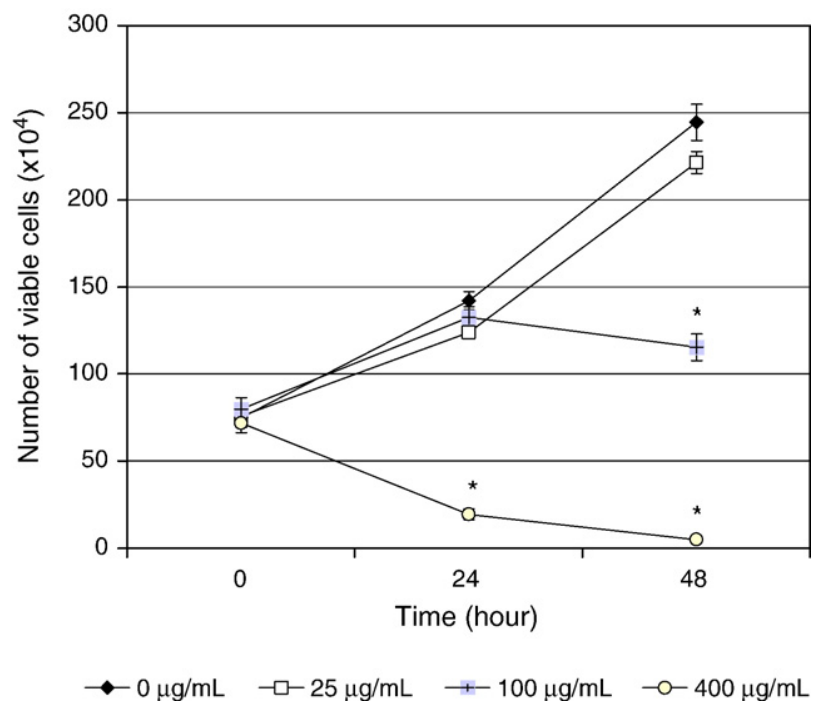

Fig. 2. Total number of viable HTC cells exposed to different concentration of Ac06 extract $(0,25,100$ and $400 \mu \mathrm{g} / \mathrm{mL})$ at 0,24 and $48 \mathrm{~h}$ of exposure. Data expressed as means \pm standard error. * Significant difference with control cells $(0 \mu \mathrm{g} / \mathrm{mL})(p<0.05)$.

\subsection{Assessment of intracellular ROS formation}

Cellular suspensions $\left(5 \times 10^{5}\right.$ cell $\left./ \mathrm{mL}\right)$ were exposed to extracts of marine sponges in medium for $24 \mathrm{~h}$. The cells were then washed twice with PBS and incubated for $30 \mathrm{~min}$ at $37^{\circ} \mathrm{C}$ with the fluorogenic compound $2^{\prime}, 7^{\prime}$-dichlorofluorescin diacetate $\left(\mathrm{H}_{2} \mathrm{DCF}-\mathrm{DA}\right)$ at a final concentration of $40 \mu \mathrm{M}$, according to previously described methods (Myhre and Fonnum, 2001). $\mathrm{H}_{2}$ DCF-DA passively diffuses through cellular membranes and once inside, the acetates are cleaved by intracellular esterases. Thereafter, the non-fluorescent compound $\mathrm{H}_{2} \mathrm{DCF}$ is oxidized by ROS to the fluorescent compound DCF. After loading with $\mathrm{H}_{2}$ DCF-DA, the cells were washed twice with PBS. Each treatment was performed in triplicate. Aliquots of $160 \mu \mathrm{L}$ of each sample (five replicates) were placed into an ELISA plate and the fluorescence intensity was measured

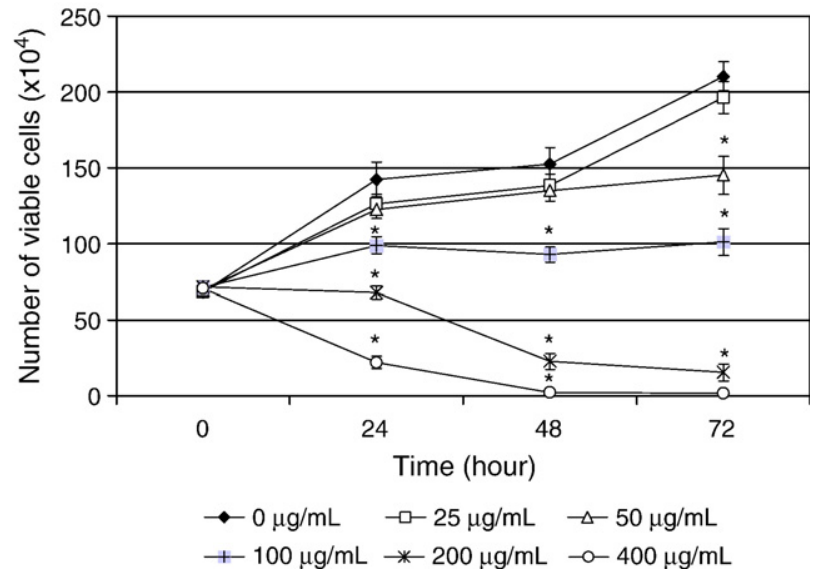

Fig. 3. Total number of viable HTC cells exposed to different concentration of Ac06H extract $(0,25,50,100,200$ and $400 \mu \mathrm{g} / \mathrm{mL})$ at $0,24,48$ and $72 \mathrm{~h}$ of exposure. Data expressed as means \pm standard error. * Significant difference with control cells $(0 \mu \mathrm{g} / \mathrm{mL})(p<0.05)$. 
Table 2

Estimated $\mathrm{Ac} 06 \mathrm{H}$ extract concentration $(\mu \mathrm{g} / \mathrm{mL})$ that reduced $50 \%$ of the total viable cell number and viability $\left(\mathrm{EC}_{50}\right)$ in $\mathrm{HTC}$ cell line

\begin{tabular}{cll}
\hline Time & $\mathrm{EC}_{50}(\mu \mathrm{g} / \mathrm{mL})$ based in cell number & $\mathrm{EC}_{50}(\mu \mathrm{g} / \mathrm{mL})$ based in viability \\
\hline $24 \mathrm{~h}$ & 308.45 & 303.74 \\
& $(276.66-349.67)$ & $(276.16-336.85)$ \\
$48 \mathrm{~h}$ & 178.82 & 172.10 \\
& $(162.00-197.25)$ & $(157.73-186.96)$ \\
$72 \mathrm{~h}$ & 159.71 & 156.60 \\
& $(145.43-175.72)$ & $(143.44-169.92)$ \\
\hline
\end{tabular}

Values between brackets represent the $95 \%$ confidence interval for each $\mathrm{EC}_{50}$ estimate.

during 90 min at $37{ }^{\circ} \mathrm{C}$, using a fluorimeter (Victor 2, Perkin Elmer), with excitation and emission wavelengths of 485 and $520 \mathrm{~nm}$, respectively. ROS levels were expressed in terms of fluorescence area, after fitting fluorescence data to a second order polynomial and integrating between 0 and $90 \mathrm{~min}$ in order to obtain its area and expressed as FU min.

\subsection{Anti-tuberculosis assay}

The method chosen for the determination of antimycobacterial activity was the Resazurin microtiter assay (REMA) (Palomino et al., 2002). Concisely, the assay was carried out in microplates ( 96 wells) using resazurin as an indicator of cellular viability. The cultivation medium employed was 7H9 (4.7 g of Middlebrook $7 \mathrm{H} 9$ broth base [Difco-Becton Dickinson] enriched with $10 \%$ Oleic Acid, albumin, dextrose and catalase). The extracts were weighed, dissolved in DMSO, and their antimycobacterial activity was evaluated at an initial concentration of $400 \mu \mathrm{g} / \mathrm{mL}$ against M. tuberculosis $\mathrm{H}_{37} \mathrm{Rv}$ (ATCC 27294) and maintained in Ogawa-Kudoh media for about 14 days, propagated from bacterial suspensions in sterile water containing $3 \mathrm{~mm}$ glass beads. The suspension was homogenized by agitation and the turbidity was adjusted in agreement with tube one of the McFarland scale $\left(3.2 \times 10^{3} \mathrm{cfu} / \mathrm{mL}\right)$. The strain inoculum was prepared starting from that suspension, diluted 1:25 in Middlebrook $7 \mathrm{H} 9$ broth (Becton Dickinson, Sparks, MD, USA) supplemented with $0.2 \%$ glycerol. The extracts from each sponge were assayed in triplicate. After 7 days of incubation, $20 \mu \mathrm{L}$ of resazurin (Applied Research Institute) solution was added to each well, incubated $48 \mathrm{~h}$ at $37^{\circ} \mathrm{C}$, and assessed for color development. A change from blue to pink indicated a reduction of resazurin and therefore bacterial growth. The MIC was defined as the lowest drug concentration that prevented this color change.

\subsection{Statistical analysis}

In the cytotoxic assay, each experiment was repeated in three independent trials, using triplicates in each trial. Data are expressed as means \pm standard error and analyzed with ANOVA followed by unequal Tukey's multiple range test. $p$-Values below 0.05 were considered statistically significant. Values of $\mathrm{EC}_{50}$ and their respective $95 \%$ confidence intervals were determined according to the American Public Health Association (1976).
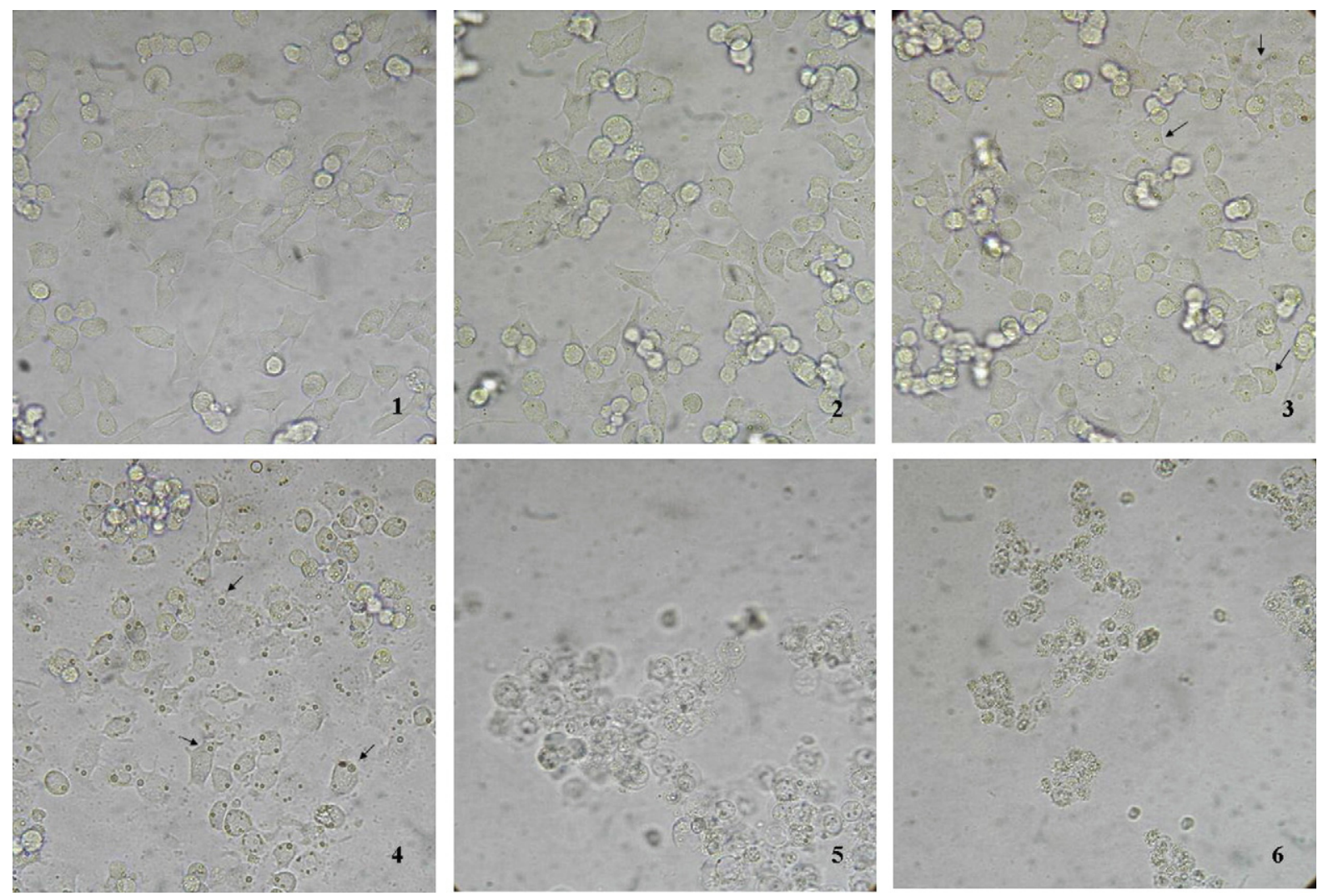

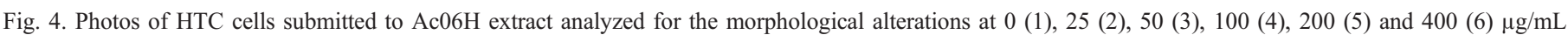
concentrations after $72 \mathrm{~h}$ exposure to extract in inverted microscopy (400×). The arrows in photos 3 and 4 demonstrated an increased amount of vacuoles. 


\section{Results}

\subsection{Cytotoxicity assay}

These results were expressed as percent viability (Table 1) and as total number of viable cells (Figs. 1-3).

The tests started with Ac05 extract. As shown in Table 1, the extract was cytotoxic only at concentrations of $1000 \mu \mathrm{g} / \mathrm{mL}$ and $2000 \mu \mathrm{g} / \mathrm{mL}$. Viability decreased following a dose/time response curve. Immediately after the exposure to extract there was no significant difference $(p>0.05)$ between control viability $(96.71 \pm 0.42 \%)$ and treated cells. In addition, no cytotoxic effects were observed with a concentration of $500 \mu \mathrm{g} / \mathrm{mL}$, however a capacity for growth inhibition was evident at $72 \mathrm{~h}$ $\left(88.62 \pm 6.82 \times 10^{4}\right.$ cell $\left./ \mathrm{mL}\right)$ when compared with control cells $\left(212.83 \pm 6.68 \times 10^{4}\right.$ cell $\left./ \mathrm{mL}\right)$ (Fig. 1$)$.

In accordance with pilot studies (data not published) Ac06 extract was tested at concentrations of 25,100 , and $400 \mu \mathrm{g} / \mathrm{mL}$, and exposure times of 0,24 , and $48 \mathrm{~h}$. Table 1 demonstrates a toxic effect at $400 \mu \mathrm{g} / \mathrm{mL}$ after $48 \mathrm{~h}$, and Fig. 2 shows growth inhibition at $100 \mu \mathrm{g} / \mathrm{mL}$ after $48 \mathrm{~h}\left(115.33 \pm 7.62 \times 10^{4}\right.$ cell $\left./ \mathrm{mL}\right)$ as compared to control cells $\left(244.4 \pm 10.42 \times 10^{4} \mathrm{cell} / \mathrm{mL}\right)$.

Finally, Ac06H extract was tested. Since Ac06 exhibited greater activity than Ac05 extract, we decided to amplify the scale of concentrations and exposure times for the $\mathrm{Ac} 06 \mathrm{H}$ extract. Results obtained are shown in Table 1 and Fig. 3. Comparing Ac06 and Ac06 $\mathrm{H}$ extracts, we observed that these extracts exhibited similar effects. During all the $72 \mathrm{~h}$ of exposure, we observed a decrease $(p<0.05)$ in cell viability at $200 \mu \mathrm{g} / \mathrm{mL}$ and at $400 \mu \mathrm{g} / \mathrm{mL}$ (Table 1). This toxic effect was concentration and time dependent. In contrast, cell viability at 25, 50 and $100 \mu \mathrm{g} / \mathrm{mL}$ concentrations was not statistically different from control $(p>0.05)$. In spite of this lack of cytotoxicity at 25,50 and $100 \mu \mathrm{g} / \mathrm{mL}$, the exposure of HTC cells to $50 \mu \mathrm{g} / \mathrm{mL}$ resulted in growth inhibition after $72 \mathrm{~h}(145.14 \pm$ $12.65 \times 10^{4}$ cell $\left./ \mathrm{mL}\right)$, again as compared with control cells $\left(210.5 \pm 9.47 \times 10^{4}\right.$ cell $\left./ \mathrm{mL}\right)$. Treatment with $100 \mu \mathrm{g} / \mathrm{mL}$ inhibited cell growth during the entire $72 \mathrm{~h}(71.22 \pm 4.2 ; 98.75 \pm 5.5$; $92.77 \pm 4.9$ and $101 \pm 8.89\left(\times 10^{4}\right.$ cell $\left./ \mathrm{mL}\right)$, respectively $)$ when

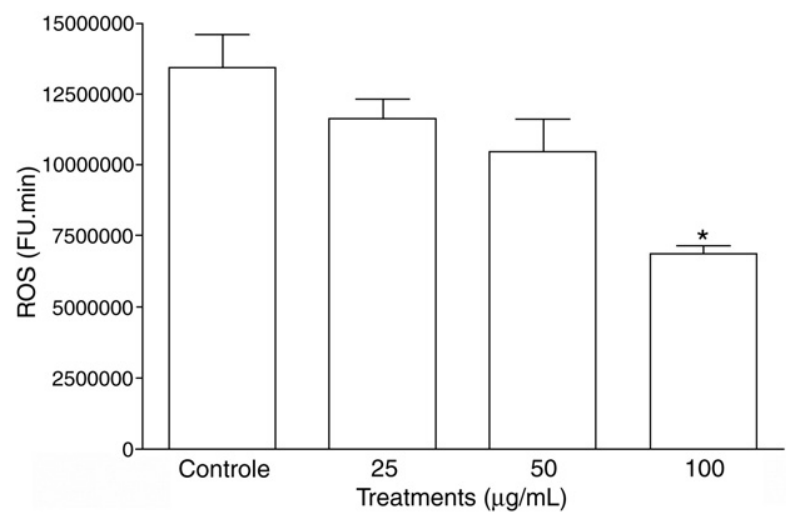

Fig. 5. Reactive oxygen species production (FU min) in HTC cells exposed to 25, 50 and $100 \mu \mathrm{g} / \mathrm{mL}$ concentrations of $\mathrm{Ac06H}$ extract for $24 \mathrm{~h}$. Data are expressed as mean \pm 1 standard error $(n=3) . *$ Significant difference with control cells $(0 \mu \mathrm{g} / \mathrm{mL})(p<0.05)$.
Table 3

Minimal inhibitory concentration of $\mathrm{Ac05}$, Ac06 and $\mathrm{Ac} 06 \mathrm{H}$ extracts that inhibits the Mycobacterium tuberculosis

\begin{tabular}{ll}
\hline Aplysina caissara extract & $\mathrm{MIC} \mu \mathrm{g} / \mathrm{mL}$ \\
\hline Ac05 & 200 \\
Ac06 & 200 \\
Ac06H & 400 \\
\hline
\end{tabular}

compared with control $(68.11 \pm 3.11 ; 142.25 \pm 11.48 ; 152.57 \pm$ 10.89 and $210.5 \pm 9.47\left(\times 10^{4}\right.$ cell $\left.\left./ \mathrm{mL}\right)\right)$ (Fig. 3).

Table 2 shows the $\mathrm{EC}_{50}$ based on viable cell number and cell viability percentage for the $\mathrm{Ac} 06 \mathrm{H}$ extract. The $\mathrm{EC}_{50}$ values at $48 \mathrm{~h}$ and $72 \mathrm{~h}$ were similar. These values were about $50 \%$ lower than those obtained at $24 \mathrm{~h}$.

Fig. 4 shows the cell images (1, 2, 3, 4, 5 and 6) displaying morphological alterations provoked by the different concentrations of extract. The control cells and those exposed to $25 \mu \mathrm{g} / \mathrm{mL}$ of Ac06H extract appear in photo 1 and photo 2, respectively, and no difference was observed between them. In photo 3 (cells exposed to $50 \mu \mathrm{g} / \mathrm{mL}$ ) one may observe the presence of vacuoles. Photo 4 demonstrates an increased number of vacuoles and morphological alterations that suggest a loss of adherence capacity, although the cell viability was no different. Photo 5 shows a total loss of adherence capacity and demonstrates a high percentage of dead cells. Finally, photo 6 shows cellular death and disintegration.

\subsection{Assessment of intracellular ROS formation}

The production of intracellular ROS was evaluated after exposure for $24 \mathrm{~h}$ to $\mathrm{Ac} 06 \mathrm{H}$ extract at concentrations of 25,50 and $100 \mu \mathrm{g} / \mathrm{mL}$. At 25 and $50 \mu \mathrm{g} / \mathrm{mL}$, no significant difference was observed when compared with control cells. Fig. 5 shows a significant decrease in the ROS formation at $100 \mu \mathrm{g} / \mathrm{mL}$ $(p<0.05)\left(86.88 \times 10^{5} \pm 3.53 \times 10^{5} \mathrm{FU} \mathrm{min}\right)$ compared to control $\left(134.48 \times 10^{5} \pm 11.33 \times 10^{5} \mathrm{FU} \mathrm{min}\right)$.

\subsection{Anti-microbial assay}

The MIC of Ac05, Ac06 and Ac06H extracts were 200, 200 and $400 \mu \mathrm{g} / \mathrm{mL}$, respectively. There was no difference among different solvents or time of collection of the sponge (Table 3).

\section{Discussion}

The results obtained in the present study indicate that extracts of A. caissara were toxic and inhibited proliferation of a hepatoma cell line.

However, it is evident that different concentrations of Ac05 and Ac06 extracts are needed to produce this effect. To show a cytotoxic effect, it was necessary to use at least $1000 \mu \mathrm{g} / \mathrm{mL}$ of the Ac05 extract, while for the Ac06 extract, $400 \mu \mathrm{g} / \mathrm{mL}$ was sufficient. With regard to proliferation inhibition, $500 \mu \mathrm{g} / \mathrm{mL}$ of the Ac05 extract was needed to produce inhibition, which was observed at $72 \mathrm{~h}$. On the contrary, a much lower dose $(100 \mu \mathrm{g} / \mathrm{mL})$ and exposure time ( $48 \mathrm{~h}$ ) was sufficient for Ac06 extract to inhibit hepatocyte proliferation. 
At least $200 \mu \mathrm{g} / \mathrm{mL}$ of the $\mathrm{Ac} 06 \mathrm{H}$ extract was needed to obtain a decrease in HTC viability. This extract also exhibited proliferation inhibition at lower concentrations (100 and $50 \mu \mathrm{g} / \mathrm{mL}$ ). Comparing proliferation inhibition capacities between Ac06 and Ac06H extracts at $100 \mu \mathrm{g} / \mathrm{mL}$, we observed a quicker response (24 h earlier) with the Ac06H extract.

Regarding the potential difference between the extracts, at least two proposals merit consideration: 1 ) the fact that the $\mathrm{Ac} 05$ extract had been directly immersed in ethanol while the Ac06 extract was immediately frozen and after some time immersed in ethanol; 2) the collection of the sponges occurred in different seasons.

The first proposal is supported by literature that demonstrates that interactions between sponge metabolites and alcohol solvents affect metabolite activity. It has been reported that dibromotyrosine metabolites of the sponge Aplysina aerophoba can degrade in the presence of alcohol-H2O mixtures, since enzymatic activity is not completely suppressed under such conditions (Ebel et al., 1997). Nevertheless, similar experiments carried out with extracts of the sponges $A$. insularis and A. archeri species demonstrated that dibromotyrosine metabolites of these sponges did not suffer degradation when stored in alcohol (Puyana et al., 2003).

The second proposal is based on the hypothesis that seasonal changes can alter the production of active chemical compounds. This has been demonstrated in the Red Sea sponge Negombata magnifica which possesses the compounds Latrunculin A and B. The concentrations of these compounds were analyzed in both the summer and winter. The results of this study revealed that the yield of latrunculins was higher in the winter (Khalifa et al., 2006). New experiments will be performed by our group to better understand these relationships between seasonal collections of our yield of bioactive compounds.

In light of our more promising result with the Ac06, this extract was partially purified by partitioning with hexane. Ac06 and $\mathrm{Ac} 06 \mathrm{H}$ extracts demonstrate similar activity, which suggests that the active metabolites are not in the lipid fraction (apolar fraction) of the extract since when this portion was removed with hexane, the extract did not diminish in activity.

In the future, new purification and isolation assays will be performed with the Ac06H extract, as it may be possible that A. caissara extracts possess greater activity and specificity when their individual components are isolated.

Acosta and Rodríguez (1992) discussed that cytotoxic effects of chemical agents on cells may include altered morphology, failure of the cell to attach to surfaces, or changes in the rates of cell processes such as growth, death and disintegration. These effects were also observed in this study.

With regard to intracellular ROS formation, the results obtained in our study contribute to the controversy in the literature. The bioactivity of the defense metabolites dienone and aeroplysinin-1 from the A. aerophoba sponge can be partly explained by their capacity to form free radicals that can destroy cells; these metabolites show cytotoxicity against human cancer cell lines (Koulman et al., 1996). This relationship between cytotoxic effects and reactive oxygen species generation has also been suggested by Matsumoto et al. (2003) where these authors purposed that ascididemin isolated from a Didemnиm sp. tunicate was cytotoxic probably by direct iminoquinone reduction and reactive oxygen species generation. On the other hand, the relevant literature reports that several sponge metabolites exhibit antioxidant activity. Some examples include: the compound 2-octaprenyl-1, 4-hydroquinone and 2-(24-hydroxy)octaprenyl-1, 4-hydroquinone isolated from the sponge Ircinia spinosula, which exhibits a strong interaction with the 2,2diphenyl-1-picrylhydrazyl radical (DPPH, a stable radical) and exhibited a significant anti-lipid peroxidation effect (Tziveleka et al., 2002); also Takamatsu et al. (2003) revealed that different sponges possess metabolites such as $(1 S)-(+)$-curcuphenol, aaptamine, isoaaptamine, and curcudiol, all with strong antioxidant activity in the DPPH assay.

In this work, was demonstrated an antioxidant activity for the Ac06H extract in the ROS assay.

Concerning anti-TB activity, our results indicate that all extracts possess a moderate activity. With regard to the Ac06 extract, when compared with the results obtained in cytotoxicity assay, our expectations were that this extract would show greater activity in the anti-TB assay when compared to Ac05 extract. Contrary to this expectation, Ac05 and Ac06 extracts possessed the same MIC activity $(200 \mu \mathrm{g} / \mathrm{mL})$, showing that independent of the extraction methodology and collection season, the active compound(s) was present in both extracts. In addition, it was also noted that the Ac06H extract, partially purified by hexane extraction, suffered a decrease in its activity when compared with Ac06 extract. It is possible that the lipid portion removed by hexane may be involved in anti-TB activity.

Some authors have demonstrated anti-microbial activity of isolated marine sponge compounds. In A. caissara, the products Fistularin-3 and 11-hydroxyaerothionin displayed moderate antibiotic activity against several pathogenic bacteria (Lira et al., 2006). The authors observed this effect from Fistularin-3 against $E$. coli ATCC 25922 (MIC at $300 \mu \mathrm{g} / \mathrm{mL}$ ) and oxacillin resistant $S$. aureus strain 8 (MIC at $600 \mu \mathrm{g} / \mathrm{mL}$ ). It is possible that other isolates may show greater activity than crude extracts. In accordance with this prospect, Oliveira et al. (2006), screened 500 crude extracts of marine invertebrates as inhibitors of M. tuberculosis $\mathrm{H} 37 \mathrm{Rv}$ and discovered that extracts from Aplysina cauliformis and Pachychalina sp. displayed antimycobacterial activity with an MIC value $<200 \mu \mathrm{g} / \mathrm{mL}$. However, these authors revealed that the known bromotyrosine alkaloid Fistularin-3 from $A$. cauliformis was active against $M$. tuberculosis with an MIC value of $8.03 \mu \mathrm{g} / \mathrm{mL}$.

The results demonstrated in this present study suggest that marine sponge extracts possess a broad potential for pharmacological applications.

\section{Acknowledgments}

This work was supported by grants from CNPq, CAPES and Fundação Universidade Federal do Rio Grande.

\section{References}

Acosta, A.L., Rodríguez, A.D., 1992. 11-Oxoaerothionin: a cytotoxic antitumour bromotyrosine-derived alkaloid from the Caribbean marine sponge Aplysina lacunosa. Journal of Natural Products 55 (7), 1007-1012. 
American Public Health Association, American WaterWorks Association, Water Pollution Control Federation, 1976. Standard Methods for the Examination of Water and Wastewaters. American Public Health Association, Washington, DC.

Ebel, R., Brenzinger, M., Kunze, A., Gross, H., Proksh, P., 1997. Wound activation of prototoxins in marine sponge Aplysina aerophoba. Journal of Chemical Ecology 23 (5), 1451-1461.

Encarnación, R.D., Sandoval, E., Malmstrom, J., Christophersen, C., 2000. Calafianin, a bromotyrosine derivative from the marine sponge Aplysina gerardogreeni. Journal of Natural Products 63, 874-875.

Faulkner, D.J., 2002. Marine natural products. Natural Product Reports 19, $1-48$.

Hamann, M.T., Scheuer, P.J., 1993. Biogenetically diverse, bioactive constituents of a sponge, order, Verongida: Bromotyramines and Sesquiterpene-Shikimate derived metabolites. Journal of Organic Chemistry 58, 6565-6569.

Hunt, B., Vincent, A.C.J., 2006. Scale and sustainability of marine bioprospecting for pharmaceuticals. Ambio 35 (2), 57-64.

Khalifa, S., Ahmed, S., Mesbah, M., Youssef, D., Hamann, M., 2006. Quantitative determination of latrunculins $\mathrm{A}$ and $\mathrm{B}$ in the Red sea sponge $\mathrm{Ne}$ gombata magnifica by high performance liquid chromatography. Journal of Chromatography. B, Analytical Technologies in the Biomedical and Life Sciences 17; 832 (1), 47-51.

Kijjoa, A., Sawangwong, P., 2004. Drugs and cosmetics from the sea. Marine Drugs 2, 73-82.

Kondo, K., Nishi, J., Ishibashi, M., Kobayashi, J., 1994. Two new tryptophanderived alkaloids from the Okinawan marine sponge Aplysina sp. Journal of Natural Products 57, 1008-1011.

Koulman, A., Proksch, P., Ebel, R., Beekman, A.C., Uden, W.V., Konings, A.W.T., Pedersen, J.A., Pras, N., Woerdenbag, H.J., 1996. Cytotoxicity and mode of action of aeroplysinin-1 and related dienone from the sponge Aplysina aerophoba. Journal of Natural Products 59, 591-594.

Kraljevic, S., Sedic, M., Scott, M., Gehrig, P., Schlapbach, R., Pavelic, K., 2006. Casting light on molecular events underlying anti-cancer drug treatment: what can be seen from the proteomics point of view? Cancer Treatment Reviews 32, 619-629.

Lira, T.O., Berlinck, R.G.S., Nascimento, G.G.F., Hadju, E., 2006. Further dibromotyrosin-derived metabolites from the marine sponge Aplysina caissara. Journal of the Brazilian Chemical Society 7 (7), 1233-1240.

Matsumoto, S.S., Biggs, J., Copp, B.R., Holden, J.A., Barrows, L.R., 2003. Mechanism of ascididemin-induced cytotoxicity. Chemical Research in Toxicology 16, 113-122.

Mayer, A.M.S., Hamann, M.T., 2004. Marine pharmacology in 2000: marine compounds with antibacterial, anticoagulant, antifungical, anti-inflammatory, antimalarial, antiplatelet, anti-tuberculosis, and antiviral activities; affecting the cardiovascular, immune, and nervous systems and other miscellaneous mechanisms of action. Marine Biotechnology 6, 37-52.

Mayer, A.M.S., Hamann, M.T., 2005. Marine pharmacology in 2001-2002: marine compounds with anthelmintic, antibacterial, anticoagulant, antidiabetic, antifungal, anti-inflammatory, antimalarial, antiplatelet, antiprotozoal, antituberculosis and antiviral activities; affecting the cardiovascular, immune and nervous systems and other miscellaneous mechanisms of action. Comparative Biochemistry and Physiology. Part C, Pharmacology Toxicology \& Endocrinology 140, 265-286.

Mayer, A.M.S., Gustafson, K.R., 2006. Marine pharmacology in 2003-2004: antitumour and cytotoxic compounds. European Journal of Cancer 42, 2241-2270.

Monks, N.R., Lerner, C., Henriques, A.T., Farias, F.M., Schapoval, E.E.S., Suyenaga, E.S., Rocha, A.B., Schwartsmann, G., Mothes, B., 2002. Anticancer, antichemotactic and antimicrobial activities of marine sponges collected off coast of Santa Catarina, southern Brazil. Journal of Experimental Marine Biology and Ecology 281, 1-12.

Munro, M.H.G., Blunt, J.W., Dumdei, E.J., Hickford, S.J.H., Lill, R.E., Li, S., Battershill, C.N., Duckworth, A.R., 1999. The discovery and development of marine compounds with pharmaceutical potential. Journal of Biotechnology 70, 15-25.

Myhre, O., Fonnum, F., 2001. The effect of aliphatic, naphthenic, and aromatic hydrocarbons on production of reactive oxygen species and reactive nitrogen species in rat brain synaptosome fraction: the involvement of calcium, nitric oxide synthase, mitochondria and phospholipase A. Biochemical Pharmacology $62,119-128$.

Nachega, J.B., Chaisson, R.E., 2003. Tuberculosis drug resistance: a global threat. Clinical Infectious Diseases 36 (Suppl 1), S24-S30.

Nicholas, G.M., Eckman, L.L., Newton, G.L., Fahey, R.C., Ray, S., Bewley, C.A., 2003. Inhibition and kinetics of Mycobacterium tuberculosis and Mycobacterium smegmatis mycotiol-S-conjugate amidase by natural products inhibitors. Bioorganic \& Medicinal Chemistry 11, 6001-6608.

Oliveira, M.F., Oliveira, J.H.H.L., Galetti, F.C.S., Souza, A.O., Silva, C.L., Hadju, E., Peixinho, S., Berlinck, R.G.S., 2006. Antimycobacterial brominated metabolites from two species of marine sponges. Planta Medica 72, 437-441.

Palomino, J.C., Martin, A., Camacho, M., Guerra, H., Swings, J., Portaels, F., 2002. Resazurin microtiter assay plate: simple and inexpensive method for detection of drug resistance in Mycobacterium tuberculosis. Antimicrobial Agents and Chemotherapy 46 (8), 2720-2722 (Aug.).

Pinheiro, U.S., Hadju, E., 2001. Shallow-water Aplysina nardo (Aplysinidae, Verongida, Dermospogiae) from the São Sebastião Channel and its environs (tropical southwestern Atlantic), with the description of a new species and a literature review of other Brazilian records of the genus. Revista Brasileira de Zoologia 18 (Suppl.1), 143-160.

Puyana, M., Fenical, W., Pawlik, J.R., 2003. Are there activated chemical defenses in sponges of genus Aplysina from Caribbean? Marine Ecology. Progress Series 246, 127-135.

Rattan, A., Kalia, A., Ahmad, N., 1998. Multidrug-resistant Mycobacterium tuberculosis: molecular perspectives. Emerging Infectious Diseases 4 (2), 195-209.

Rodriguez, A., Piña, I., 1993. The structures of Aplysinamisines I, II and III: new bromotyrosine-derived alkaloids from the Caribbean sponge Aplysina cauliformis. Journal of Natural Products 56 (6), 907-914.

Saeki, B.M., Granato, A.C., Berlinck, R.G.S., Magalhães, A., Schefer, A.B., Ferreira, A.G., Pinheiro, U.S., Hadju, E., 2002. Two unprecedented dibromotyrosine-derived alkaloids from the Brazilian endemic marine sponge Aplysina caissara. Journal of Natural Products 65, 796-799.

Silva, P.E.A., Osório, M., Reinhardt, M.C., Fonseca, L.S., Dellagostin, O.A., 2001. Drug resistance of strains of Mycobacterium tuberculosis isolated in Brazil. Microbes and Infection 3, 1111-1113.

Souza, M.V.N., 2006. Research article, marine natural products against tuberculosis. The Scientific World Journal 6, 847-861.

Takamatsu, S., Hodges, T.W., Rajbhandari, I., Gerwick, W.H., Hamann, M.T., Nagle, D.G., 2003. Marine natural products as novel antioxidant prototypes. Journal of Natural Products 66, 605-608.

Tziveleka, L.-A., Kourounakis, A.P., Kourounakis, P.N., Roussis, V., Vagias, C., 2002. Antioxidant potential of natural and synthesized hydroquinones. Bioorganic \& Medicinal Chemistry 10, 935-939.

Urban, S., Hickford, S.J.H., Blunt, J.W., Munro, M.H.G., 2000. Bioactive marine alkaloids. Current Organic Chemistry 4, 765-807.

WHO, 2000. World Health Organization Tuberculosis Fact Sheet. No. 104. WHO, 2006. World Health Organization Tuberculosis Fact Sheet. No. 104. 